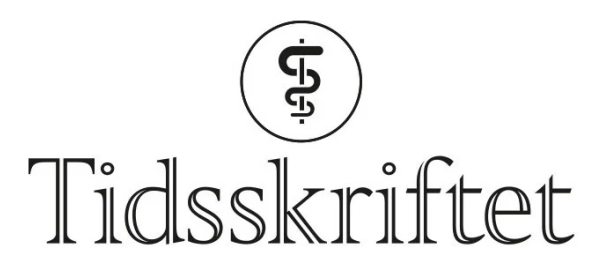

DEN NORSKE LEGEFORENING

\title{
Legers rolle i Nye metoder
}

DEBATT

\section{IVAR SØNBØ KRISTIANSEN}

i.s.kristiansen@medisin.uio.no

Ivar Sønbø Kristiansen er professor emeritus ved Avdeling for helseledelse og helseøkonomi ved Universitetet i Oslo. Hans forskningsinteresser er blant annet prioritering og $ø$ konomisk evaluering. Forfatteren har fylt ut ICMJE-skjemaet og oppgir følgende interessekonflikter: Han har mottatt lønn, honorar, måltider, reisestøtte og gaver fra en lang rekke offentlige institusjoner og private for-profit og non-for-profit institusjoner inklusive legemiddelfirmaer.

\section{ASLAK SYSE}

Aslak Syse er dr.jur., lege og professor emeritus ved Institutt for offentlig rett ved Universitetet i Oslo. Han har særlig arbeidet med helserettslige og velferdsrettslige spørsmål.

Forfatteren har fylt ut ICMJE-skjemaet og oppgir ingen interessekonflikter.

\section{Legenes rolle i prioriteringssystemet Nye metoder er uklar og dårlig definert, og det mangler åpenhet om deres medisinskfaglige vurderinger. Dette er konklusjoner i en nylig offentliggjort evaluering av ordningen.}

Nye metoder er et prioriteringssystem som ble innført for spesialisthelsetjenesten i 2013. Ordningen innebærer at alle nye legemidler og enkelte utstyrstyper skal evalueres av Statens legemiddelverk eller Folkehelseinstituttet. Beslutningsforum, som består av de fire direktørene i de regionale helseforetakene, bestemmer på bakgrunn av evalueringene hvorvidt legemidler og utstyr skal innføres i spesialisthelsetjenesten. Leger gir innspill til evalueringsrapportene, som kalles metodevurderinger, og til retningslinjer for bruken av metoder som blir godkjent av Beslutningsforum.

Proba samfunnsanalyse fikk oppdraget med evaluering av Nye metoder og har nylig publisert sin rapport (1). Vi har vært eksterne medlemmer i arbeidsgruppen bak denne evalueringen. Rapporten er omfattende, men enkelte punkter er særlig relevante for leger som arbeider i spesialisthelsetjenesten: For det første er den medisinskfaglige medvirkningen i utarbeidelsen av metodevurderinger svak, for det andre er legenes rolle ikke klart definert, og for det tredje er det ikke åpenhet om legenes medvirkning i Nye metoder.

\section{Ressurser og prioritering}


Nye metoder er i prinsippet et prioriteringssystem for alle deler av spesialisthelsetjenesten, men i praksis brukes det først og fremst for legemidler. Legemidler utgjorde 3,9 \% (4,3 milliarder kroner) av de regionale helseforetakenes kostnader i 2014 og $\varnothing$ kte til 5,8 \% (9,o milliarder) i 2021. Overføring av finansieringsansvar fra Helfo til de regionale helseforetakene er den viktigste årsaken til kostnadsveksten, som reelt var omtrent null i perioden 2018-2020.

Prioriteringsmeldingen tilsier at samfunnet skal prioritere helsetiltak ut fra tiltakenes nytte, som måles i gode leveår, ressursbruk (kostnad) og helsetilstandens alvorlighet (2). Kriteriene betyr i praksis at ved prioritering mellom behandlinger skal både alvorlighet og effekt tillegges vekt, ikke bare kostnad og pris.

\section{Klinikermedvirkning i metodevurdering}

Når Folkehelseinstituttet og Legemiddelverket utarbeider metodevurderinger for Beslutningsforum, inviteres klinikere til å bidra. Medvirkningen skjer ved at klinikerne svarer på spørsmål i e-postutveksling eller møter. Det utarbeides ikke referater med omtale av spørsmål og svar, og klinikerne er ikke involvert i utformingen av evalueringstekst eller konklusjoner.

Hematologen Fredrik Schjesvold, som har vært involvert i metodevurderinger, sier følgende: «Statens legemiddelverk gjør vurderinger med hensikt å øke kostnaden for å skape gode forhandlingskort overfor industrien. [...] Jeg er for prioritering, men systemet må være redelig, uavhengig og transparent. I dag er det ingen av delene» (3).

«Rangeringen er basert på legemiddelkostnad og ulike andre kostnader, men ikke på effekt»

I evalueringen av Nye metoder sier Proba at man oppfatter fra flere aktører «en ganske sterk misnøye med klinikermedvirkningen i Nye metoder, men [at] det er andre som er fornøyd. Misnøyen handler om at mange metodevurderinger, og dermed også beslutninger, ikke bygger på forutsetninger som samsvarer med god klinisk praksis» (1, s. 169). I evalueringen heter det videre: «Vi mener det bør tydeliggjøres hvilken rolle klinikere skal ha, og det bør dokumenteres i metodevurderingsrapportene hvilken rolle de har hatt. Hvis man viderefører hovedtrekkene i dagens modell for klinikermedvirkning, bør man tydeliggjøre klinikernes bidrag og synspunkter. De bør sikres rimelig tid på å lese utkast til sluttrapport fra metodevurderingen.»

\section{Likeverdige legemidler?}

Når legemidler er godkjent av Beslutningsforum, gjennomfører helseforetaket Sykehusinnkjøp anbudsinnkjøp og utarbeider retningslinjer for bruken av legemidlene. Retningslinjene innebærer en prioritering mellom legemidler, er bindende for klinikerne og skal, som annen virksomhet $\mathrm{i}$ helsetjenesten, følge de vedtatte prioriteringskriteriene. I retningslinjene rangeres legemidlene for ulike tilstander, og klinikeren skal innen hver tilstand velge det høyest rangerte (prioriterte) legemidlet dersom ikke bivirkninger, manglende effekt eller andre forhold taler for å forskrive et lavere rangert legemiddel. Slike avvik skal begrunnes og journalføres.

Rangeringen er basert på legemiddelkostnad og ulike andre kostnader, men ikke på effekt. Legemidlene i den enkelte rangeringsliste er nemlig antatt å være likeverdige, men Sykehusinnkjøp publiserer ikke møtereferater som kan belyse om ulikheter i effekt har vært vurdert. Sykehusinnkjøp oppnevner legespesialistgrupper for ulike behandlingsområder så som kreft, multippel sklerose mv. Spesialistgruppenes oppgave er 
blant annet å gi innspill ved utarbeidelse av anbudsutlysinger og retningslinjer med rangering av legemidler. Deres virksomhet skal følge prinsippene for prioritering (므) ved at de opererer innenfor et lovfestet forvaltningssystem. Dersom rangering av legemidler skjer på grunnlag av kostnad alene, må de behandlingene som rangeres, ha (omtrent) samme effekt - altså være likeverdige. En sentral funksjon for spesialistgruppene er altså å vurdere likeverdighet. Sykehusinnkjøp anfører følgende om likeverdighet: «Hva som defineres som faglig likeverdig må defineres for hvert enkelt terapiområde i det til enhver tid gjeldende konkurransegrunnlag» (4). . Definisjonen har ingen henvisning til Legemiddelverkets metodevurderinger, som nettopp analyserer effektforskjeller mellom legemidler.

\section{«Det er viktig at klinikere som deltar i beslutningsprosessene, forholder seg til prioriteringskriteriene»}

Tidligere helse- og omsorgsminister Bent Høie fremmet "pasientens helsetjeneste» og medvirket til å få såkalte brukerrepresentanter i diverse komiteer og grupper. Dersom nåværende minister Ingvild Kjerkol følger samme linje, vil det være naturlig å styrke spesialistgruppene med brukerrepresentanter for å få pasientvurderinger av likeverdighet.

Evalueringen av Nye metoder nevner blant annet lymfomlegemidlet obinutuzumab (Gazyvaro) som eksempel på en tvilsom vurdering av likeverdighet (1, s. 183). Legemiddelverket anslo i en metodevurdering at obinutuzumab gir o,59 flere leveår $(0,50$ kvalitetsjusterte leveår) per pasient enn den alternative behandlingen basert på rituksimab (5). Sykehusinnkjøp har imidlertid bedømt de to behandlingene som likeverdige og rangert rituksimab foran obinutuzumab basert på pris. Denne rangeringen kan være i strid med gjeldende prioriteringskriterier som tilsier at både kostnad og effekt er prioriteringskriterier. Eksempelet er neppe enestående for så vidt som ulike psoriasislegemidler er vurdert som likeverdige til tross for at randomiserte studier viser ulik effekt (ㅁ). Dersom en behandling har bedre effekt, men høyere kostnad enn alternativet, kan den likevel få prioritet dersom mereffekten står i et rimelig forhold til merkostnaden.

\section{Åpenhet}

Nye metoder har bred prinsipiell støtte blant pasientrepresentanter, helsepersonell og produsenter av legemidler og annen teknologi. I Probas rapport framheves som en hovedkonklusjon at det likevel er til dels betydelig mistillit til systemet. Det heter blant annet at «enkelte sår også tvil om Folkehelseinstituttet og Legemiddelverket er balanserte i sine metodevurderingsrapporter eller om de i stedet understøtter målet om priskontroll» $(1$, s.3). Det kan være mange grunner til denne mistilliten, men manglende åpenhet om prosesser er trolig en viktig faktor.

Denne mangelen på åpenhet gjør seg også gjeldende når det gjelder spesialistkomiteene og klinikeres bistand i metodevurderinger. Større åpenhet og derved tillit kan oppnås gjennom å utarbeide operasjonaliserbare kriterier for faglig likeverdighet, offentliggjøre referater fra spesialistgruppenes møter og bruke skriftlig, åpen kommunikasjon der klinikere bistår i metodevurderinger.

Det er viktig at klinikere som deltar i beslutningsprosessene og arbeidet med grunnlaget for disse, forholder seg til prioriteringskriteriene. Andre interessenter kan i utgangspunktet slutte seg til kriteriene, men i de konkrete vurderingene om innføring av et nytt medikament kan «egeninteressene» lett ta overhånd. Legemiddelfirmaer er selvfølgelig interessert i å «selge inn» så mange medikamenter som mulig. Pasientorganisasjonene vil på sin side være mest interessert $\mathrm{i}$ at ingen medikamenter med potensiell effekt skal kunne avvises på grunn av prisnivået (kostnadskriteriet). Særlig gjelder dette dersom medikamentene synes å kunne ha en effekt hos pasienter i den 
aktuelle pasientpopulasjonen. Relevante aktører kan derved ha interesser som går ut over den konsensus som ligger til grunn for lovgivningen og systemet for prioritering. Her vil klinikere kunne ha en bredere tilnærming, selv om de i den kliniske hverdagen enkelte ganger også ønsker å være «pasientens advokat».

Et viktig spørsmål er om enkeltpasienter kan ha rett til behandling etter pasient- og brukerrettighetsloven når behandlingen ikke er godkjent av Beslutningsforum. Dette temaet ble etter $\emptyset$ nske fra departementet ikke belyst i evalueringen av Nye metoder. Et $\varnothing$ kende antall slike saker vil trolig tvinge departementet til en avklaring der leger kan spille en viktig rolle.

\section{Konklusjon}

Systemet for Nye metoder i spesialisthelsetjenesten fungerer ikke slik at legers medvirkning gjør at prinsippene for prioritering i norsk helsetjeneste lett kan oppfylles. Den medisinskfaglige medvirkning er svak, og legenes rolle er ikke klart definert. Det er ikke åpenhet om de innspill leger gir i Nye metoder. Legeforeningen bør bidra til at leger som bistår Nye metoders organer, får grundig innføring i gjeldende prioriteringskriterier og prinsippene for metodevurdering slik at Nye metoder kan oppfylle sitt samfunnsoppdrag.

\section{LITTERATUR}

1. Evaluering av systemet for Nye metoder i spesialisthelsetjenesten. Rapport 16-2021. Oslo: Proba samfunnsanalyse, 2021.

https://www.regjeringen.no/contentassets/o9874ao573eb480384061da473458ed1/rapport-evalueringnye-metoder-2021115-ferdig.pdf Lest 9.12.2021.

2. Meld. St. 34 (2015-2016). Verdier i pasientens helsetjeneste. Melding om prioritering. Oslo: Helse- og omsorgsdepartementet, 2015 .

https://www.regjeringen.no/contentassets/439a420eo1914a18b21f351143ccc6af/no/pdfs/stm20152016o03 4ooodddpdfs.pdf

3. Ingen pasienter får den beste behandlingen for benmargskreft. Dagens Medisin 4.4.2019. https://www.dagensmedisin.no/artikler/2019/04/04/-altfor-fa-aktuelle-studier-for-pasienter-i-norge/ Lest 8.12.2021.

4. Håndbok. Retningslinjer for innføring av legemidler i spesialisthelsetjenesten i sammenheng med anskaffelser. Oslo: Sykehusinnkjøp, 2020.

https://nyemetoder.no/Documents/Beslutninger/H\%C3\%A5ndbok\%2oversjon\%201.0\%20-01.07.2020.pdf Lest 8.12.2021.

5. Hurtig metodevurdering Gazyvaro (obinutuzumab) til førstelinjebehandling av avansert langsomtvoksende follikulært lymfom i kombinasjon med kjemoterapi. Vurdering av innsendt dokumentasjon. Oslo: Statens legemiddelverk, 2017.

https://nyemetoder.no/Documents/Rapporter/Obinutuzumab\%2o-\%2oHMV\%2omed\%2oprisnotat.pdf. Lest 18.11.2021.

6. Warren RB, Gooderham M, Burge R et al. Comparison of cumulative clinical benefits of biologics for the treatment of psoriasis over 16 weeks: Results from a network meta-analysis. J Am Acad Dermatol 2020; 82: 1138-49. [PubMed][CrossRef]

Publisert: 16. desember 2021. Tidsskr Nor Legeforen. DOI:10.4045/tidsskr.21.0823

Mottatt 23.11.2021, første revisjon innsendt 29.11.2021, godkjent 3.12.2021.

(C) Tidsskrift for Den norske legeforening 2023. Lastet ned fra tidsskriftet.no 26. april 2023. 